Aletria, Belo Horizonte, v. 30, n. 4, p. 131-154, 2020

(c) (1)

\title{
A tradução de antíteses em Amor es más laberinto, de Sor Juana Inés de la Cruz
}

\section{The Translation of Antitheses in Sor Juana Inés de la Cruz's Amor es más laberinto}

\author{
Andréa Cesco \\ Universidade Federal de Santa Catarina (UFSC), Florianópolis, Santa Catarina / Brasil \\ andrea.cesco@gmail.com \\ http://orcid.org/0000-0002-4708-186X \\ Mara Gonzalez Bezerra \\ UNIASSELVI, Florianópolis, Santa Catarina / Brasil \\ mara.gonzalez.letras@gmail.com \\ http://orcid.org/0000-0001-8390-5910
}

Resumo: Este artigo apresenta e comenta a tradução ao português, ainda inédita, de alguns fragmentos da obra teatral Amor es más laberinto (1689), escrita por Sor Juana Inés de la Cruz (1651-1695) e Juan de Guevara (1654-1692). A edição, de 2010, pela Cátedra, é da renomada pesquisadora Celsa Carmen García Valdés. O foco da análise está em uma amostra significativa de antíteses, próprias da estética barroca, definidas a partir dos estudos de Lausberg (2004), que apresentam dificuldades tradutórias, principalmente em função da distância histórica e cultural. $\mathrm{O}$ ato tradutório está centrado nos pressupostos de Berman (2013) e Venuti (2002). Também são contextualizados o texto literário teatral (PAVIS, 2008), as traduções da escritora no Brasil e a sua escrita, sobretudo com base em Octavio Paz (1989, 1990), assim como aspectos do Século de Ouro espanhol, com relação aos recursos estilísticos utilizados e as influências literárias refletidas na obra.

Palavras-chave: Amor es más laberinto; Sor Juana Inés de la Cruz; tradução literária; antítese. 


\begin{abstract}
This paper presents and comments on the as yet unpublished translation of some fragments of the play Amor es más laberinto [Love Is the Greater Labyrinth] (1689), written by Sor Juana Inés de la Cruz (1651-1695) and Juan de Guevara (1654-1692). The 2010 edition was edited by the renowned researcher Celsa Carmen García Valdés, and published by Cátedra. The analysis focuses on a relevant sample of antitheses -a figure of speech typical of baroque aesthetics, as defined according to the studies of Lausberg (2004)-, which pose translation difficulties, mainly due to historical and cultural distance. The translation act is centered on the assumptions of Berman (2013) and Venuti (2002). Additionally, the theatrical literary text (PAVIS, 2008), and the Brazilian translations of the Mexican poetess and her writings are contextualized, drawing particularly on Octavio Paz (1989, 1990), as well as aspects of the Spanish Golden Age, with regard to the stylistic resources used and the literary influences reflected in the work.
\end{abstract}

Keywords: Love is the Greater Labyrinth; Sor Juana Inés de la Cruz; literary translation; antithesis.

\title{
Introdução
}

A peça teatral Amor es más laberinto ([1689] 2010), da mexicana Sor Juana Inés de la Cruz (1651-1695), em parceria com Juan de Guevara (1654-1692), foi escrita com o objetivo de ser encenada à corte mexicana na despedida do vice-rei, que retornava à Espanha, e para dar as boasvindas ao sucessor. Os aspectos literários, próprios do Barroco e do Século de Ouro espanhol, refletem-se na escrita dos 3.630 versos.

A vice-rainha Condessa de Paredes, no retorno do México a Madri, levou consigo os manuscritos de Sor Juana, que resultaram na publicação da obra Inundación Castálida (1689) - composta por poesias, villancicos, sonetos, letras sacras e autos sacramentais -, o que trouxe à escritora um êxito imediato e a consagrou como a mais relevante do período Barroco hispano-americano.

Amor es más laberinto é a única obra escrita em parceria: Juan de Guevara escreveu o ato dois e Sor Juana os atos um e três. A peça teatral, que não contém nenhum elemento cristão, é considerada pela crítica literária como profana (PAZ, 1990), porque o enredo remete à mitologia grega, com o mito do Minotauro de Creta e o fio de Ariadne, típicos do Barroco. Os mundos da escritora oscilam entre o sacro e o profano, a corte e o convento. Assim, a antítese - com sentimentos como 
amor-gratidão, vingança-perdão, entre outros - é um elemento estético recorrente em sua obra, e largamente utilizado por escritores do Século de Ouro espanhol, como Quevedo, Lope de Vega e Cervantes.

Sendo assim, este artigo objetiva apresentar fragmentos da tradução, ao português, da peça teatral Amor es más laberinto (referentes aos atos 1 e 3), com destaque para a análise das antíteses, que apresentam significativas dificuldades tradutórias, em especial em função da distância histórica e cultural. A edição utilizada é a da respeitada pesquisadora Celsa Carmen García Valdés, pela Cátedra, coleção Letras Hispánicas, de 2010. Como suporte teórico, busca-se o apoio em Berman (2013), Venuti (2002), Pavis (2008) e Lausberg (2004), entre outros.

\section{Sor Juana Inés e a obra teatral Amor es más laberinto}

Juana de Asbaje y Ramírez de Santillana ou Sor Juana Inés de la Cruz, como seria chamada após os votos confessionais, nasceu em 1651, no México, e faleceu em 1695, com 44 anos. Durante sua vida no convento de São Jerônimo escreveu a maior parte da sua obra literária e teve, posteriormente, um lugar reservado no Olimpo das letras hispanoamericanas.

A sua vida e os seus feitos são considerados excepcionais para o tempo em que viveu, pois se destacou em diversas áreas que eram do predomínio de homens. Além de ser freira, escritora, contadora, administrando as contas do Mosteiro de São Jerônimo, também cuidava de sua família, gerenciando as finanças pessoais.

O frontispício de Inundación Castálida (1689), na sua primeira publicação em Madri, tinha a inscrição de Décima Musa. E, depois, em 1700, na portada de Fama y Obras Póstumas, acrescentavam-se os dizeres "Fênix do México", um prenúncio dos títulos pelos quais ela seria lembrada posteriormente. De acordo com $\operatorname{Paz}(1989$, p. 21, tradução nossa): "não é apenas a figura mais alta da poesia colonial hispanoamericana, mas também um dos espíritos mais valiosos e profundos de nossas letras".

Sor Juana caminhou com desenvoltura por um longo período entre diversos espaços e entre mundos bastante antagônicos, o que pode ser

\footnotetext{
${ }^{1}$ No original: "no solamente es la figura más alta de la poesía colonial hispano-americana sino que es también uno de los espíritus más ricos y profundos de nuestras letras."
} 
observado como um movimento dialético e constante, traduzido em um movimento antitético. Nota-se, em sua literatura, o cuidado para não cair em desgraça diante das autoridades, tanto civis como eclesiásticas, pois tinha sua própria opinião a respeito de temas considerados como tabus ou heresias pela Igreja Católica. Utilizava temas extraídos dos mitos gregos, os mesmos de Ovídio nas Metamorfoses, evitando os teológicos, pois corria menos risco de cair no desagrado civil e religioso (Inquisição).

A escritora, desde criança, procurou estratégias próprias para adquirir conhecimentos e, mais tarde, quando jovem, tanto na corte como no convento, obteve um acesso maior a conhecimentos científicos e culturais, algo inesperado para uma mulher do período colonial, pois as preocupações femininas deveriam ser outras. Os espaços em que ela viveu, tão antagônicos entre si - fazenda, corte e convento -, metaforicamente também são uma antítese e, sem dúvida, contribuíram em muito na sua formação intelectual.

Paz (1990) enumera alguns dos temas abordados por Sor Juana em sua literatura e mostra como sempre se moveu entre o sacro e o profano, conforme já mencionado, pois a cultura que detinha possibilitava a inclusão de temas além dos esperados na época para uma freira: "Ao contrário das escolas filosóficas da Antiguidade, cujo objetivo era sabedoria e vida justa, nenhum guia místico cristão prescreve o estudo de minerais, da botânica, da física e da matemática para alcançar a Deus" (PAZ, 1990, p. 495, tradução nossa). ${ }^{2}$ Os temas teológicos tratados também se apresentam a partir de uma perspectiva dialética, como livrearbítrio versus predestinação, em que o homem pode realizar escolhas que apontam para um pensamento teológico pluralizado que contempla diversas correntes dentro do Cristianismo.

No período colonial de 1600 , o teatro era uma atividade plenamente aceita e implementada na sociedade, como forma de divertimento. $\mathrm{O}$ gênero fazia parte da vida social, independente do estrato social no qual a pessoa estava inserida. De acordo com Mário Gonzalez, "o teatro espanhol em língua castelhana chega ao seu auge no século XVII e constitui uma das manifestações culturais de maior relevância nessa centúria" (GONZÁLEZ, 2010, p. 393). Assim, era um

2 No original: "A diferencia de las escuelas filosóficas de la Antigüedad, cuyo fin último eran la sabiduría y la vida recta, ninguna guía mística cristiana prescribe el estudio de los minerales, la botánica, la física y las matemáticas para llegar a Dios". 
fato que inúmeros autores desse período escrevessem peças para serem representadas, como forma de diversão para todos.

E embora, muitas vezes, o teatro tenha sido demonizado pela igreja católica durante um período da história, retomou seu lugar com as reformas monásticas beneditinas (DINIZ, 2008, p. 76), quando passou a ter um fim didático ou de exaltação às virtudes cristãs. Sor Juana, séculos depois, uniu essas duas vertentes em suas peças teatrais: o profano (didático), representado pelas mitologias, quer gregas ou latinas, e o sacro, em que as referências bíblicas estão presentes. Na peça Amor es más laberinto - levando em conta o fato de ter sido escrita por um sacerdote e uma freira - não há nenhuma menção a temas cristãos, o que permite considerá-la como profana.

Quanto à estrutura, Sor Juana mantém o estilo espanhol vigente: "O aspecto formal característico do teatro espanhol clássico será a opção pelo modelo que fragmenta a obra em três atos, modelo esse que se apoia na tripartição do conflito dramático em: apresentação, desenvolvimento e desfecho" (GONZÁLEZ, 2010, p. 355). A escritora segue o exemplo de Lope de Vega, com três atos, mas inova nas unidades aristotélicas de tempo e espaço.

O enredo de Amor es más labirinto tem como pano de fundo um tema bem conhecido da mitologia grega - o Minotauro de Creta. No entanto, há na história os elementos dramáticos de capa e espada, próprios do Barroco. O roteiro refaz a história de Teseu, enviado como tributo ao rei de Creta. O príncipe de Atenas desperta o amor das infantas, Ariadne e Fedra. Na luta contra o Minotauro, Teseu triunfa e sai do labirinto. Mas, isso só acontece porque Ariadne lhe oferece uma saída inteligente do labirinto: o fio desenrolado ao longo da entrada marcará o caminho de saída. Daqui em diante será uma sucessão de confusões graciosas e amorosas até o final da obra, onde as infantas acabam por ter, cada uma, o seu par: Teseu fica com Fedra e Ariadne com Baco.

Sor Juana coloca no mesmo nível príncipes e princesas e dá voz, ao longo da obra, às criadas e criados. Entre os temas abordados, notase um ponto de partida diferente: uma mulher assume o protagonismo e resolve o problema da saída do labirinto, cuja solução inteligente para o enigma residia na simplicidade do fio. A escritora dizia: "yo no estimo riquezas ni tesoros... sino conocimiento" (DE LA CRUZ, 2000, p. 254). Assim, a peça teatral contrapõe, nas atitudes dos personagens, algumas das concepções do período colonial hispano-americano, vivenciadas 
na sociedade da época (BASSNETT, 1980, p. 123). Nessas tomadas de decisões é que sua escrita dialética se manifesta fortemente, pois Sor Juana não nega o heroísmo de Teseu e suas grandes conquistas, mas coloca em cena uma heroína que transpõe os mais diversos obstáculos para livrar da morte o objeto de seu amor.

\section{As traduções de Sor Juana no Brasil}

No Brasil, os pesquisadores da extensa obra literária de Sor Juana, assim como do Século de Ouro espanhol, ainda são poucos, embora os cursos de Letras, em especial os de língua espanhola, incluam-na em seus currículos. Ela chegou ao público brasileiro, fora do âmbito acadêmico, por algumas de suas obras.

Os livros já traduzidos ao português do Brasil estão esgotados e fora do mercado editorial de consumo imediato. Lançados todos em apenas uma primeira edição, há algumas décadas, carecem de reedições ou novas traduções. As poucas traduções existentes são porções esporádicas e/ou parcas, e pertencem todas ao século passado. O fato é que, se não há procura pelo autor, as traduções não se tornam "urgentes" ou necessárias. No Brasil, escritores do Século de Ouro espanhol, como Sor Juana, Quevedo, Lope de Vega ou o próprio Cervantes acabam por se restringir aos pesquisadores acadêmicos ou aos poucos amantes dessa literatura.

Ao se pesquisar os textos traduzidos ao português e publicados no Brasil, verificou-se que Manuel Bandeira (1886-1968) foi o pioneiro, apresentando Sor Juana ao público brasileiro no livro Estrêla da tarde, pela José Olympio, em 1963, com tradução das obras Loa para el auto sacramental del Divino Narciso e El Narciso Divino.

Em 1989, organizado por Tereza Cristófani Barreto, temos Letras sobre o Espelho - Sor Juana Inês de la Cruz, pela Iluminuras. Os textos em prosa, O Sonho (Primer Sueño) e Carta de Sor Filotea de la Cruz (Carta Atenagórica), foram traduzidos por Tereza Cristófani Barreto. Quanto aos textos em verso (12 sonetos, 1 lira e 1 sátira filosófica), oferecidos no Quadro 1, estes foram traduzidos por Vera Mascarenhas de Campos. 
QUADRO 1 - Textos em verso

\begin{tabular}{|l|l|}
\hline & $\begin{array}{l}\text { "Procura desmentir los elogios que a un retrato de la Poetisa } \\
\text { inscribió la verdad, que llaman pasión"; "Quéjase de la suerte: } \\
\text { insinúa su aversión a los vicios, y justifica su divertimiento a las } \\
\text { Musas"; "En que da moral censura a una rosa, y en ella a sus } \\
\text { semejantes"; "Escoge antes el morir que exponerse a los ultrajes } \\
\text { de la vejez"; "Encarece de animosidad la elección de estado } \\
\text { durable hasta la muerte"; "Muestra sentir que la baldonen por } \\
\text { los aplausos de su habilidad"; "Sospecha crueldad disimulada, el } \\
\text { alivio que la esperanza da"; "Verde embeleso"; "Que contiene una } \\
\text { fantasía contenta con amor decente"; "Prosigue el mismo asunto, } \\
\text { y determina que prevalezca La razón contra el gusto"; "Que } \\
\text { consuela a un celoso, epilogando La serie de los amores"; "A una } \\
\text { pintura de Nuestra Señora, de muy excelente pincel". }\end{array}$ \\
\hline Lira & $\begin{array}{l}\text { "Que expresan el sentimiento que padece una mujer amante, de su } \\
\text { marido muerto". }\end{array}$ \\
\hline Sátira filosófica & "Hombres Necios" \\
\hline
\end{tabular}

Fonte: Elaborado pelas autoras do artigo.

Em 1990, pela Nova Fronteira, Aurélio Buarque de Holanda Ferreira traduz quatro sonetos da escritora, publicados em Grandes vozes líricas hispano-americanas (edição bilíngue). São eles: "De una reflexión cuerda con que mitiga el dolor de una pasión"; "En que satisface un recelo con la retórica del llanto"; "Alaba, con especial acierto el de un músico primoroso"; "Resuelve la cuestión de cuál sea pesar más molesto en encontradas correspondencias, amar o aborrecer".

A última publicação com textos de Sor Juana, de 2000, é a obra Poetas do século de ouro espanhol/Poetas del siglo de oro español (edição bilíngue). A obra, que teve seleção e tradução de Anderson Braga Horta, Fernando Mendes Vianna e José Jeronymo Rivera, inclui um estudo introdutório de Manuel Morillo Caballero. Publicada em Brasília, sob os auspícios da Consejería de Educación y Ciencia de la Embajada de España, a obra compõe a coleção Orellana, n. 12. Nela há uma seleção de 4 poemas de Sor Juana: "Arguye de Inconsecuentes el Gusto y la Censura de los Hombres que en las Mujeres Acusan lo que Causan"; "Al que ingrato me deja, busco amante"; "Cuando mi error con tu vileza veo"; "En que Satisface un Recelo con la Retórica del Llanto". 
A partir desse levantamento, sobre as obras traduzidas e publicadas da escritora mexicana no Brasil, percebe-se o quanto ela e a sua obra se encontram esquecidas e marginalizadas, e da urgência que se faz em resgatá-la desse limbo que já completa duas décadas.

\section{Análise de tradução das antíteses em Amor es más labirinto}

A tradução da peça Amor es más laberinto parte do pressuposto de não apagar a escrita dialética presente, em função do jogo constante e contraditório de palavras usadas nas falas dos personagens. As antíteses construídas por Sor Juana são pensadas e colocadas no texto sempre com uma finalidade, o que acaba por exigir uma atenção por parte do tradutor em manter a letra (BERMAN, 2013), a estrutura criada, o ritmo do texto, pois estas podem passar desapercebidas e assim perder de vista o jogo e os processos criativos da sua escrita.

Berman (2013) apresenta o ato de traduzir como um compromisso ético com o texto, por parte do tradutor, a fim de preservar as características que o tornam único. Ainda afirma que um texto traduzido não deve ser etnocêntrico e/ou servil. Coincide com outros estudiosos o fato de que o leitor seja levado ao autor, e não o contrário, para não incorrer em uma "domesticação textual"; este termo, cunhado por Venuti (2002), torna-se completo para expressar o quanto uma tradução pode servir a interesses escusos.

Albergar Sor Juana em língua portuguesa compreende um conjunto formado pela reflexão e pela prática do tradutor literário. O labor remete não somente a toda leitura e preparação prévia, mas também às experiências e aos saberes incluídos na bagagem do tradutor. A tradução da peça Amor es más laberinto se constituiu em um desafio, em alguns momentos, porque leva em conta o que também Venuti reforça sobre a ética da tradução: "o reconhecimento das diferenças culturais" (VENUTI, 2002, p. 352), evidenciadas nos textos de partida e chegada. Ambos os teóricos - Berman e Venuti - acreditam que é importante tirar o leitor de sua zona de conforto e obrigá-lo a refletir sobre a leitura, e isso pressupõe em mais atenção do tradutor nas escolhas realizadas e um projeto de tradução conscientemente elaborado.

Berman (2013), ao dissertar sobre a prática da tradução, diz que ela perpassa pela cognição do tradutor, mais do que por qualquer cartilha teórica, e se reflete no texto traduzido. A ação do elemento humano, de 
organizar o texto e levá-lo a outra língua, marca a diferença. Não contribui em muito saber como e por que uma tradução deva ser realizada, se ela não tiver um significado para o outro, ou seja: "A tradução pode perfeitamente passar sem teoria, não sem pensamento" (BERMAN, 2013, p. 24).

A escrita de Sor Juana reflete, conforme já mencionado, o modelo literário do Século de Ouro espanhol. Por isso, modificar ou apagar, na tradução da peça, as antíteses construídas acaba diminuindo a intensidade do argumento desenvolvido para os personagens e, consequentemente, acaba influenciando na maneira como o leitor sente a obra. São as figuras que criam a tensão na peça e dão um colorido semântico ao texto, que contrapõe as emoções e libera ao leitor as sensações exuberantes e marcantes, típicas de uma leitura barroca.

Para agrupar os casos de antíteses é utilizada a nomenclatura sugerida por Lausberg em Manual de Retórica Literária (2004), obra escolhida para o embasamento teórico sobre a figura de pensamento. A antítese é definida a princípio como "contraposição de dois pensamentos de volume sintático variável” (LAUSBERG, 2004, p. 228). No entanto, o autor oferece diretrizes para agrupá-las, o que facilita a sua classificação e os casos em que ocorre: antíteses frásicas, antíteses de grupos de palavras e antíteses de palavras isoladas.

A seguir, a partir dos fragmentos selecionados - que são apenas uma amostra representativa das antíteses (dentro das mencionadas categorias) - busca-se oferecer propostas de tradução, com possíveis soluções, seguidas de comentários e reflexões sobre os versos analisados.

\subsection{Antíteses frásicas (ou de frase)}

Reconhecer uma antítese a partir de léxicos antônimos entre si é o começo, mas não basta. Segundo Lausberg (2004, p. 229), "são contrapostas, entre si, proposições inteiras, entre si relacionadas pela coordenação ou por qualquer outra relação sintática (proposições principais ou subordinadas)"; os conectivos e a pontuação são os auxiliares presentes na organização do enunciado e podem na coordenação ser assindéticas ou sindéticas.

Neste fragmento, a partir do monólogo do criado de Baco, Racimo, sabe-se que este precisa entregar o bilhete que desafia para um duelo o Príncipe Lidoro. Racimo, temendo por sua própria vida, astuciosamente busca outra pessoa para a tarefa, sem imaginar as desgraças que a sua atitude vai causar ao seu amo Baco. 
QUADRO 2 - Fragmento 1

\begin{tabular}{|l|l|}
\hline \multicolumn{1}{|c|}{ RACIMO } & \multicolumn{1}{c|}{ RACIMO } \\
$\begin{array}{l}\text { [...] temiendo que el tal Lidoro } \\
\text { quiera, por el porte, hacerme } \\
\text { merced de ensayar conmigo } \\
\text { la pendencia, me parece } \\
\text { que es mejor buscar algún } \\
\text { paje que el papel le lleve, } \\
\begin{array}{l}\text { y antes que él me dé los tajos, } \\
\text { darle yo con los reveses. }\end{array}\end{array}$ & $\begin{array}{l}\text { queira, pelo porte, usar-me } \\
\text { como meio de ensaio } \\
\text { Versos 2391 a 2398 (DE LA CRUZ, 2010, p. 428. } \\
\text { Grifo nosso) }\end{array}$ \\
\hline
\end{tabular}

Fonte: Elaborado pelas autoras do artigo.

Sor Juana parte de elementos conhecidos de seu plenário e forma antíteses com as figuras corriqueiras do dia a dia. Neste caso, utiliza nomes de golpes dados por armas brancas. Os elementos de romance de cavalaria marcam os versos sublinhados (QUADRO 2) que são antitéticos entre si. O campo semântico de tajos e reveses estão interligados à esgrima, ao desafio do duelo, como forma de reparo, e às relações amo/ criado. Também na artimanha do criado de procurar por um pajem para entregar, em seu lugar, o bilhete ecoa o pícaro dos romances espanhóis e que sempre, como forma de sobrevivência, articula uma estratégia para se livrar de um possível castigo ou para aproveitar-se de uma benesse.

$\mathrm{O}$ medo de Racimo remete à fragilidade dos criados ou daqueles destinados a servir, já que uma vez criado não havia perspectiva de mudança de status social, e a posição ocupada impunha a realização de tarefas com risco da própria vida. Sor Juana conhecia isso de perto, porque a convivência nos diversos ambientes legou-lhe uma visão crítica da sociedade colonial mexicana.

A dificuldade da tradução dos versos (QUADRO 2) reside nas palavras tajo e reveses, por serem movimentos clássicos da esgrima. Tanto o leitor de língua espanhola como o de português podem não reconhecer os termos específicos pelo fato de não viver em uma época de capa e espada ou mesmo por não acompanhar a esgrima como esporte. Entende-se, na leitura dos versos, que são movimentos contrários e que há um jogo de 
palavras. No entanto, como Solana (2005, p. 252, tradução nossa) nos adverte:

O tradutor não pode, como costumamos fazer enquanto leitores, passar por cima de uma palavra cujo significado desconhece (embora saiba como traduzi-la), ou que lhe é meio familiar (e isso acontece com mais frequência do que pensamos); ou pular uma frase porque lhe é ininteligível, ou tomar a decisão de resumir um parágrafo que lhe parece muito complexo. ${ }^{3}$

De acordo com o Diccionario de la Real Academia Española, os verbetes tajo e revés apresentam as seguintes acepções: "tajo diagonal: Esgr. Tajo que se tira en la línea diagonal que atraviesa el cuadrado que se considera en el rostro". E revés: "Esgr. Golpe que se da con la espada diagonalmente, partiendo de izquierda a derecha." Ambos os verbetes se referem ao golpe desferido, na esgrima, com a espada ou outra arma branca, e a direção do movimento, se direita ou esquerda. Ou seja, são movimentos contrários em uma luta e que trazem uma especificidade.

É possível também encontrar ecos de outras leituras na escrita de Sor Juana, como, por exemplo, em Lope e Cervantes. As mesmas palavras são encontradas em Peribañez y el Comendador de Ocaña, de Lope de Vega, nos versos: "Mas, mientras los gallardos paladines / armados tiran tajos y reveses, / presentóle Medoro unos chapines" (VEGA, 2003, n.p., grifo nosso). A comédia de Lope, ainda sem tradução para o português do Brasil, explicita o contexto nos versos, pois relaciona as armas à nobreza dos paladinos.

Também no Quijote, de Cervantes - em forma de paródia podem-se encontrar os termos analisados: "mas no por esto dejaba de menudear don Quijote cuchilladas, mandobles, tajos y reveses como llovidos" (CERVANTES, 2007, p. 335, grifo nosso). Na tradução ao português, de Sérgio Molina, o trecho mencionado ficou assim: "mas nem por isso deixava D. Quixote de amiudar cutiladas, mandobles, talhadas

\footnotetext{
${ }^{3}$ No original: "El traductor no puede, como hacemos muchas veces como lectores, pasar por encima de una palabra cuyo significado desconoce (aunque sepa cómo traducirla), o que conoce a medias (y eso sucede con más frecuencia de lo que creemos); o saltarse una frase porque le resulta ininteligible, o tomar la decisión de resumir un párrafo que a él le resulta demasiado complejo".
} 
e reveses às mãos cheias" (CERVANTES, 2007, p. 335, grifo nosso), o que deixa em aberto outras possibilidades de tradução.

Curiosamente, o Tratado das lições da espada preta e destreza, que hão de usar os jogadores (LUÍS, [1685] 2010) apresenta os movimentos escritos como "talhos" e "reveses", referindo-se às diferentes formas de estocadas da esgrima: "Daqui nasce o talho e o revés, e nesta venida obra o mais destro. No meter a espada por fora há o talho que se encontra com outro talho, nasce logo o revés que se encontra com outro revés" (LUÍS, [1685] 2010, s.p.), o que denota que "talho" e "revés", embora tenham como campo semântico "golpes", ainda que sejam contrários, não se excluem. Então, para os termos analisados, nos versos de Sor Juana, não se trata de paradoxo e sim de antítese.

No dicionário Priberam também se encontra o verbete "revés", em português, com a entrada "golpe ou cutilada dado obliquamente", definição esta que remete a uma arma branca e que Molina também usou ao traduzir cuchilladas, no excerto anterior do Quijote; "talho", no mesmo dicionário, tem a acepção de "golpe dado com instrumento cortante." Dessa forma, a solução encontrada para manter a antítese e, de acordo com Berman (2013), conduzir o leitor ao texto, foi a de manter estas palavras.

\subsection{Antíteses de grupos de palavras}

Neste grupo, a figura de pensamento não apresenta dificuldade para ser reconhecida e não apresenta muitas acepções, já que, de acordo com Lausberg (2004, p. 230), a "correspondência lexical de antagonismo, no tocante ao isocólon e à sequência linear dos elementos, são válidas as observações das frásicas". O importante é observar, a partir da contraposição de grupos de palavras entre si, como se dá e funciona a dependência sintática entre elas, se são coordenadas ou relacionadas por qualquer relação sintática, e ainda pelos elementos correspondentes entre si, mas de significação diferente (LAUSBERG, 2004, p. 213).

Neste segundo fragmento analisado, Baco, escondido, escuta a conversa entre Ariadne e sua criada, Cíntia. Ele entende que Fedra e Ariadne estão apaixonadas pelo mesmo homem. Indignado e decepcionado, questiona sobre a honra dessa pessoa que ilude as infantas e supõe que se trata de Lidoro, sem saber que a conversa era sobre Teseu. A partir desse momento se estabelece um equívoco e logo Baco envia um 
convite para duelar com Lidoro, mas que é lido pelo Príncipe de Atenas. No fim, o duelo, equivocadamente, acontece entre Lidoro e Teseu que nada tinham um contra o outro; Lidoro morre.

QUADRO 3 - Fragmento 2

\begin{tabular}{|l|l|}
\hline BACO: & BACO: \\
¡Al amante de su hermana! & Ao amante da sua irmã! \\
¿Qué es esto? ¡Triste de mí! & O que é isso? Triste de mim! \\
Que lo quisiera saber & Que o quisesse saber \\
Y no lo quisiera oír. & E não quisesse ouvir. \\
Versos 1065 a 1068 (DE LA CRUZ, & \\
2010, p. 433. Grifo nosso) & \\
\hline
\end{tabular}

Fonte: Elaborado pelas autoras do artigo.

Sor Juana utiliza o equívoco como base para a sua comédia e, por conseguinte, consegue o efeito dramático. Lope de Vega, em El Arte nuevo de hacer comedias (2003, n.p), vai dizer que "o falar equivocado, e a incerteza anfibológica, sempre teve um ótimo lugar no vulgar, porque ele pensa que só entende o que o outro diz", ${ }^{4}$ ou seja, é uma referência dos elementos que compõem a tragédia grega, como a clássica Édipo Rei.

Os dois primeiros versos (QUADRO 3), que funcionam como introdução para a antítese, constroem uma ação de surpresa, mostrando a indignação do personagem mediante a pontuação, que marca o ritmo da leitura. Assim, há o cuidado em manter as exclamações e as interrogações para introduzir dois momentos antitéticos: o de não querer saber e o de querer saber, mantendo a tensão que o personagem enfrenta e que irá desencadear o momento da peripécia, mais adiante, na comédia. Segundo Berman (2013, p. 78), "a deformação pode afetar consideravelmente a rítmica, por exemplo, ao alterar a pontuação".

Nos dois últimos versos, onde a antítese é introduzida pelos conectivos que e $y$, além da marca do advérbio de negação no, seguido

\footnotetext{
${ }^{4}$ No original: "siempre el hablar equívoco ha tenido, y aquella incertidumbre anfibológica, gran lugar en el vulgo, porque piensa que él solo entiende lo que el otro dice.”
} 
do verbo querer, está a contraposição que permite entender a oposição de sentimentos, pois, a ação aqui é negar a confirmação do conhecimento.

Uma observação necessária sobre a tradução do verbo querer, quanto ao modo e ao tempo verbal - algo recorrente na tradução de verbos entre os pares espanhol e português -, é que, muitas vezes, pode-se traduzir por analogia, como no caso de quisiera, em espanhol, e quisera, em português. Por isso, no Quadro 4, mostra-se como o verbo pode mudar e se comportar nas duas línguas.

QUADRO 4 - Tempo e modo verbal do verbo querer

\begin{tabular}{|l|l|l|l|}
\hline \multicolumn{1}{|c|}{ Modo } & \multicolumn{1}{|c|}{ Tempo } & \multicolumn{1}{c|}{ Verbo } & \multicolumn{1}{c|}{ Tradução } \\
\hline $\begin{array}{l}\text { Subjuntivo } \\
\text { (espanhol) }\end{array}$ & $\begin{array}{l}\text { pretérito imperfecto } \\
\text { ou copretérito }\end{array}$ & $\begin{array}{l}\text { quisiera } \\
\text { (espanhol) }\end{array}$ & $\begin{array}{l}\text { quisesse } \\
\text { (português) }\end{array}$ \\
\hline $\begin{array}{l}\text { Subjuntivo } \\
\text { (português) }\end{array}$ & pretérito imperfeito & $\begin{array}{l}\text { quisesse } \\
\text { (português) }\end{array}$ & $\begin{array}{l}\text { quisiera } \\
\text { (espanhol) }\end{array}$ \\
\hline $\begin{array}{l}\text { Indicativo } \\
\text { (português) }\end{array}$ & pretérito mais-que-perfeito & $\begin{array}{l}\text { quisera } \\
\text { (português) }\end{array}$ & $\begin{array}{l}\text { había querido } \\
\text { (espanhol) }\end{array}$ \\
\hline $\begin{array}{l}\text { Indicativo } \\
\text { (espanhol) }\end{array}$ & pluscuamperfecto & $\begin{array}{l}\text { había querido } \\
\text { (espanhol) }\end{array}$ & $\begin{array}{l}\text { quisera } \\
\text { (português) }\end{array}$ \\
\hline
\end{tabular}

Fonte: Elaborado pelas autoras do artigo.

A opção para os versos que contêm a antítese foi manter, na tradução, o mesmo modo e tempo verbal do espanhol porque, neste caso, o desejo de negação é considerado uma ação de possibilidade, o que ratifica o uso do subjuntivo por este pertencer à esfera do desejo de negar o fato e não de algo como concreto, pois o personagem não aceita a ideia de que Fedra está apaixonada por outro pretendente que não ele.

\subsection{Antíteses de palavras isoladas}

Aparentemente, este grupo é o tipo mais simples de ser reconhecido, já que à primeira vista se torna fácil identificar palavras cujo fundamento lexical seja o antônimo. Lausberg (2004) explica como as ocorrências acontecem: por palavras sintaticamente coordenadas; por palavras relacionadas entre si, por outra relação sintática; e por duas variantes que intensificam uma antítese: o oxímoro e o paradoxo. 
Com relação ao paradoxo e ao oxímoro, Lausberg (2004) comenta que são elementos que intensificam uma antítese. Ambos são uma construção dentro das figuras de pensamento que partem da base para formar uma antítese, mas com o diferencial de que as premissas são antagônicas e inverossímeis, causando confusão e estranheza quando enunciadas.

Um paradoxo exige uma elaboração mais acurada; na estética literária são figuras que "dizem sem dizer" ou pode, ainda, referir-se a "algo dito que não está dito"; a palavra se reveste de um novo significado e conta uma segunda história, subjacente a que é apresentada. Quanto ao oxímoro, que pode ser confundido com um paradoxo, Lausberg (2004) afirma que ele é construído a partir de antíteses, mas, com algumas particularidades: apresenta-se como uma construção menos complexa do que o paradoxo; é notadamente verossímil, enquanto um paradoxo não o é; e localiza-se em uma mesma frase, enquanto o paradoxo é formado a partir de diversas premissas.

Estas figuras, para o tradutor, constituem-se em um desafio não somente linguístico, como também cultural, pois a sutileza que uma antítese encerra, ao ser reconhecida, torna-se o calcanhar de Aquiles para um tradutor ético, no sentido bermaniano, tanto no texto de partida como no de chegada.

E para ilustrar esse grupo de antíteses, a análise se concentra em dois fragmentos do texto de Sor Juana. O fragmento a seguir trata do discurso realizado pelo príncipe Teseu diante do Rei Minos, antes da entrada no labirinto. Ele narra suas façanhas, mas também apresenta questionamentos filosóficos a respeito das relações humanas.

Uma estratégia da escritora era ter uma história como pano de fundo enquanto outra história acontecia em primeiro plano. Na peça, a história aparente é o tributo para o Minotauro e que desta vez incluía o príncipe Teseu, um dos que estavam destinados a morrer no labirinto. A outra história mostra o empoderamento feminino: a Princesa Ariadne como o fio condutor do enredo, a que detêm o poder para a liberdade do ateniense usando o que tem nas mãos, um fio, símbolo da prenda e do labor feminino, que em suas mãos se torna a chave para a saída do labirinto. 
QUADRO 5 - Fragmento 3

\begin{tabular}{|l|l|}
\hline TESEO: & TESEU: \\
Porque pensar que por sí & Porque pensar que por si \\
los hombres se sometieron & os homens se submeteram \\
a llevar ajeno yugo & a levar alheio jugo \\
y a sufrir extraño freno, & e a sofrer estranho freio, \\
si hay causas para pensarlo, & se há causas para pensá-lo, \\
no hay razón para creerlo; & não há razão para crê-lo; \\
porque como nació el hombre & porque como nasceu o homem \\
naturalmente propenso & naturalmente propenso \\
a mandar, sólo forzado & a mandar, somente forçado \\
se reduce a estar sujeto; & se reduz a estar sujeito; \\
y haber de vivir en un & e ter de viver em um \\
voluntario cautiverio, & voluntário cativeiro, \\
ni el cuerdo lo necesita & nem o cordato o necessita \\
ni quiere sufrirlo el necio. & nem quer sofrê-lo o néscio. \\
Versos 485 a 498 (DE LA CRUZ, 2010, p. 350. & \\
Grifo nosso) & \\
\hline
\end{tabular}

Fonte: Elaborado pelas autoras do artigo.

Os dois últimos versos do excerto (QUADRO 5) mostram como em Sor Juana ecoa Cervantes. Na fala do Quixote "y fui loco y ya soy cuerdo, fui Don Quijote y soy ahora como he dicho, Alonso Quijano el Bueno" (CERVANTES, 2007, p. 845, grifo nosso) um paradoxo é formado a partir das antíteses loco e cuerdo, e entre os verbos fui e soy. No jogo de antíteses, no trecho sublinhado, encontra-se uma objetiva oposição entre cuerdo e necio. Dessa forma, procurando uma solução para manter o eco de Cervantes e as antíteses formadas por Sor Juana, os versos foram traduzidos assim: "nem o cordato o necessita / nem quer sofrê-lo o néscio."

A tradução proposta por Sergio Molina, no Quixote, acabou causando uma cacofonia desnecessária: "eu fui louco, e já sou são, fui D. Quixote de La Mancha e sou agora, como disse, Alonso Quijano o Bom" (CERVANTES, 2007, p. 845, grifo nosso). 
Desta forma preferiu-se manter "néscio" e "cordato", não só para manter as escolhas lexicais que parecem apropriadas, mas por se adequarem à métrica do verso, e, principalmente, por estarem mais próximas do que a autora utilizou. Esta discussão remete a Berman, pois dentro da ética da tradução se aplica a questão da estranheza: "levar às margens da língua para a qual se traduz a obra estrangeira na sua pura estranheza sacrificando deliberadamente sua 'poética' própria" (BERMAN, 2013, p. 54).

Sor Juana, em seus textos, "abusa" das mensagens subliminares, não só porque é próprio do Barroco, mas porque caracteriza a sua escrita. E nessas aparentes contradições e paradoxos transparece seu pensamento político, cultural e social; por isso é necessária uma leitura desconfiada e reflexiva na elaboração da tradução. No trecho analisado, o príncipe discorre sobre as condições da sociedade e discute as relações de quem manda e daquele que, por ser mandado, se sujeita a situações indesejadas. O discurso de Teseu questiona como pode um ser que nasce livre crescer e se sujeitar a tantas convenções impostas pela sociedade, mantidas na perpetuação de construtos sociais.

A outra antítese, voluntario cautiverio, dá margem para mais especulações retóricas, pois como as palavras estão na mesma proposição, considera-se, a princípio, que seja um oxímoro; mas há também a formação de um paradoxo, no verso, pela condição que cada palavra representa. A palavra "cativeiro" - na oposição livre-cativo, está relacionada à situação do príncipe que se oferece como tributo em nome do bem-estar de uma nação, abdicando de opções, como a de ir e vir. Teseu levanta questionamentos sobre a liberdade humana e a abdicação dela para um poder executivo.

Em um período colonial, cuja encenação era para a corte do vicereinado, de maioria espanhola, foi ousada a escrita de Sor Juana, pois o papel atribuído à mulher-freira era o de total submissão, mas voluntária. Depois de assumido o compromisso diante dos poderes patriarcais, eclesiásticos ou reais espera-se plena aceitação ou, então, incorre-se na punição por viver em desacordo com o "padrão". Um exemplo de transgressão foi a redação da Carta Atenagórica. Sor Juana, ao criticar um sermão do Padre Vieira, expressou uma série de pensamentos religiosos e políticos e, por isso, veio a ser advertida e punida por parte de seus supervisores eclesiásticos. 
A pesquisadora hispanista Jean Franco afirma que as duas peças teatrais de Sor Juana consideradas profanas "refletem fielmente as convenções do teatro espanhol da idade de ouro" (FRANCO, 1994, p. 56, tradução nossa). ${ }^{5}$ Mas, enquanto no teatro espanhol "o mais importante é a honra do homem, no teatro de Sor Juana o mais importante é a confusão provocada pela necessidade de escolhas" (FRANCO, 1994 p. 57, tradução nossa). ${ }^{6}$ De fato, o maior dilema enfrentado por Teseu é a escolha que deve fazer entre as duas irmãs: Ariadne ou Fedra? O que escolher, gratidão ou amor? O dilema é cruel e o preço da eleição será caro, independente da opção.

No último fragmento analisado (QUADRO 6), Atum pede a Teseu que o poupe da sua fúria, após o príncipe ler indevidamente o bilhete que era endereçado a Lidoro. Atum se defende ao dizer que para aprender ou realizar melhor o seu serviço não precisa receber golpes ou açoites.

QUADRO 6-Fragmento 4

\begin{tabular}{|l|l|}
\hline ATÚN: & ATUM: \\
¡Ay de mis cascos! & Aiii, minha cabeça! \\
Espera, Señor, advierte & Espera, Senhor, percebe \\
que soy Atún y no pulpo, & que sou Atum e não polvo, \\
que con golpes se enternece. & que com golpes aprende. \\
¿Aquéstas son las albricias? & Por tanto, estas são as alvíssaras? \\
Versos 2473-2477 (DE LA CRUZ, 2010, p. 432. & \\
Grifo nosso) & \\
\hline
\end{tabular}

Fonte: Elaborado pelas autoras do artigo.

Na exclamação de Atum (o gracioso), além do tom de humor, são apresentadas duas palavras que, quando colocadas em uma sentença, adquirem um terceiro significado semântico de domínio popular à época de Sor Juana. Este verso se constitui em um problema para a tradução, à primeira vista, pois ocorre uma perda cultural no texto de chegada, para o leitor de língua portuguesa, e remete aos pressupostos de Pavis (2008)

\footnotetext{
${ }^{5}$ No original: "reflejan fielmente las convenciones del teatro español de la Edad de Oro". ${ }^{6}$ No original: "lo más importante es el honor del varón; en el teatro de Sor Juana, lo más importante es la confusión provocada por la necesidad de elegir".
} 
sobre a cultura que vai implícita em um texto fonte. Ao exclamar soy atún, encontra-se uma afirmação seguida da negação e do eu subentendido, no soy pulpo. O jogo entre soy e no soy é óbvio, no entanto, a seguir, é explicada a importância dos dois substantivos que, na verdade, estão adjetivando o personagem como uma antítese, não lexical, mas de ordem semântica.

No Diccionario de Autoridades são encontradas as seguintes entradas no verbete atún e pulpo, que interessam para a tradução da peça pelo que encerram como contexto e que, por conseguinte, constroem as oposições semânticas:

(Atún) Pescádo mui conocído, [...] CERV. Nov. 8. pl. 234. No os llameis pícaros sino haveis cursado dos cursos en la Académia de la pesca de los atúnes. [...] Por atún y vér al Duque. Locución proverbiál, que se dice quando uno con motívo de ir à hacer una diligéncia, quiere lograr otra que le importa. (grifos nossos)

(Pulpo) Pescado de mar [...] Su carne es esponjosa, y dura de digerir, por lo qual ha menester estar mui manído y golpeado para poderse comer. [...] FR. L. DE GRAN. Symb. part. 1. cap. 14. §. 1. Pues qué diremos de las astúcias de que el pulpo usa para buscar de comer? [...] Poner como un pulpo. Es castigar a alguno, dándole tantos golpes o azotes, que le dexen mui maltratado. Es tomado de lo que se hace con el Pulpo. Latín. Castigare. Verberare. (grifo nosso. A ortografia usada na época foi mantida). (grifos nossos)

O substantivo "atum", em espanhol, remete ao esperto, ao pícaro que procura sempre obter resultados que o favoreçam; também é o nome do deus de Heliópolis, que representa o sol na mitologia egípcia. $\mathrm{O}$ personagem Atum faz jus ao nome que o caracteriza na peça: um criado estrangeiro na corte, em busca do melhor negócio para salvar a própria pele, mas com personalidade e brilho próprios.

O verso também caracteriza um trocadilho, pois Atum é um nome próprio, enquanto pulpo é um animal; ou seja, na leitura é possível entender que Atum se apresenta pelo nome e mantém a sua identidade como ser humano. Por outro lado, o substantivo "polvo", entre outras acepções, se refere a uma expressão conhecida do público espanhol: poner como un pulpo, e caracteriza a pessoa que é castigada fisicamente, seja por açoites ou por golpes, o que remete ao golpes que os pescadores 
dão no polvo, com o objetivo de amaciar a carne antes de ser consumida. A condenação do castigo corporal é realizada sutilmente por Sor Juana, e isso hipoteticamente se supõe por ter vivenciado diversos espaços fazenda, corte e convento - e ter conhecido de perto as desigualdades sociais.

Nas falas do gracioso residem o humor e o protesto do criado, e se o leitor não estiver a par das acepções que os vocábulos guardam, acabará perdendo o jogo de palavras envolvido. O personagem deixa claro que é "atum" e não "polvo", brincando, ele mesmo, com palavras que remetem a animais do mar e que podem ser comparados. Mas, a comparação só faz sentido com a negação que aparece no verso seguinte, quando se tem conhecimento do que une o polvo aos golpes, e do porquê o Atum não quer ser confundido com o polvo. Uma construção frásica e imagética de animais que constituem contrários e não exatamente uma oposição lexical, mas uma semântica no contexto do verso.

$\mathrm{Na}$ tradução ao português, como as duas palavras se aproximam na escrita, estas foram mantidas. No entanto, faz-se necessário paratextos explicativos para que o leitor não perca as riquezas culturais do texto de partida.

A partir dos quatro fragmentos analisados, com relação a sua compreensão e tradução ao português, percebe-se o quanto o texto de Sor Juana permite, a cada tempo, uma nova leitura, o que o torna, de certa forma, atemporal. E quando o texto sai da mão do tradutor, este cria vida em paragens nunca antes imaginadas. Por isso há um compromisso do tradutor em resguardar as ambiguidades, as antíteses e os pensamentos velados do texto, que são a fonte na qual a comédia da escritora mexicana se nutre.

\section{Considerações finais}

A peça Amor es más laberinto, embora pertença ao período colonial hispano-americano, permite uma leitura não apenas de divertimento à corte (o que funciona como justificativa apenas aparente da peça), mas também revela nas entrelinhas as condições sociais da época, muitas delas ainda vivenciadas hoje, no século XXI. Por isso as antíteses, no texto, são importantes como camuflagem para desviar o olhar inquisitório e disfarçar, nas entrelinhas, toda a temática social. Temas como escravidão, desigualdade social, discussão sobre gênero, 
sutilmente debatidos na obra, se não estivessem disfarçados teriam gerado grandes tensões e problemas à escritora. Pode-se dizer que Sor Juana é uma das precursoras das discussões sociais e que estas são coletivas, considerando-se o meio em que foram inseridas. A leitura de sua obra ainda propicia uma discussão sobre as parcas escolhas que a mulher detinha na sociedade colonial espanhola.

Nas entrelinhas de sua obra subjaz uma segunda intenção. A escritora mexicana, de alguma forma, manipula o pensamento do leitor de forma subliminar. É perceptível, na peça, como Sor Juana prezou muito mais pela inteligência do que pela beleza, pois a primeira representa o poder, a força, e não a espada. No texto, é a sagacidade feminina que metaforicamente abre as portas de saída do labirinto.

$\mathrm{O}$ jeito transgressor de Sor Juana de pensar e escrever despertou uma censura que no fim a levou, forçadamente, a abdicar de seus bens científicos e da escrita literária. Por isso, durante toda a tradução da peça, foi lembrada a contribuição de Venuti (2002) sobre a possibilidade de manipulação do texto pelo tradutor. Neste caso, na tradução, cuidou-se para manter as marcas do discurso de Sor Juana que demonstram como ela percebia a sociedade do seu entorno.

Traduzir Amor es más laberinto envolve a cultura dos textos de partida (século XVII) e chegada e não apenas a língua, principalmente no que diz respeito aos seus significados ocultos, como expressões idiomáticas e figuras de pensamento e linguagem, abundantes no texto. As antíteses, que pontuam a emoção dos personagens, em um vaivém de pensamentos e falas, acabam por lançar o leitor em um sedutor jogo de palavras e ações. Assim, preservar na tradução, do espanhol ao português, a riqueza estética da escrita de Sor Juana, expressa através das antíteses, estabelecendo um contato entre as duas línguas e culturas, tão distantes temporalmente, significa uma postura ética frente ao texto, como mencionado por Berman (2013) e Pavis, "que respeita a proximidade e o afastamento, a familiaridade e a estranheza" (PAVIS, 2008, p. 147). 


\section{Referências}

ATÚN. In: DICCIONARIO de Autoridades (A-B). Madrid: Real Academia Española, 1726. Disponível em: http://ntlle.rae.es/ntlle/ SrvltGUISalirNtlle. Acesso em: 15 abr. 2020.

BANDEIRA, Manuel. Estrêla da tarde. Rio de Janeiro: José Olympio, 1963.

BARRETO, Tereza Cristófani; DE CAMPOS, Vera Mascarenhas (org.). Letras sobre o Espelho: Sor Juana Inés de La Cruz. Tradução de Tereza C. Barreto e Vera M. de Campos. São Paulo: Iluminuras, 1989.

BASSNETT, Susan. Translations studies. New York: Methuen, 1980.

BERMAN, Antoine. A tradução e a letra ou o albergue do longínquo. Tradução de Marie-Hélène C. Torres, Mauri Furlan, Andréia Guerini. 2. ed. Tubarão: Copiart, 2013.

CERVANTES, Saavedra Miguel de. O engenhoso cavaleiro D. Quixote de La Mancha. Tradução de Sérgio Molina. Gravuras de Gustavo Doré. Apresentação de Maria Augusta da C. Vieira. Ed. bilíngue. São Paulo: Ed. 34, 2007.

DE LA CRUZ, Juana Inés. Fama y obras póstumas. Madrid: Manuel Ruiz de Murga, 1700. Biblioteca Virtual Miguel de Cervantes. Disponível em: http://www.cervantesvirtual.com/portales/sor_juana_ines_de_la_cruz/ imagenes_cartas/imagen/imagenes_cartas_15_sor_juana_ $\overline{\text { fama }} / \overline{\text { Acesso }}$ em: 21 abr. 2020.

DE LA CRUZ, Juana Inés. Los empeños de una casa: Amor es más Laberinto. Ed. Celsa Carmen García Valdés. Madrid: Cátedra, [1689] 2010. (Coleção Letras Hispánicas)

DE LA CRUZ, Juana Inés. Poesía Lírica. Ed. de José C. González Boixo. Madrid: Cátedra, [1689] 2000. (Coleção Letras Hispánicas)

DINIZ, Alai Garcia. Livro de introdução ao estudo do texto poético e dramático. Florianópolis: LLE/CCE/UFSC, 2008.

FERREIRA, Aurélio Buarque de Holanda. Grandes vozes líricas hispano-americanas. Seleção e tradução de Aurélio Buarque de Holanda Ferreira. Rio de Janeiro: Nova Fronteira, 1990. 
GONZÁLEZ, Mario M. Leituras de literatura espanhola. São Paulo: FAPESP, 2010.

LAUSBERG, Heinrich. Elementos de retórica literária. Tradução, prefácio e aditamentos de R. M. Rosado Fernando. 5. ed. Lisboa: Fundação Calouste Gulbekian, 2004.

LUÍS, Thomás. Tratado das lições da espada preta, e destreza, que hão de usar os jugadores dela. Edição crítica de Manuel Valle Ortiz, Tomás González Ahola, Ton Puey e Jaime Girona. Santiago de Compostela (Espanha): AGEA, Edizer, [1685] 2010. Disponível em: http://migre.me/ tUoND. Acesso em: 08 mar. 2020.

PAVIS, Patrice. O teatro no cruzamento das culturas. Tradução de Nanci Fernandes. São Paulo: Perspectiva, 2008.

PAZ, Octavio. México en la obra de Octavio Paz: IV. Generaciones y semblanzas. Escritores y letras de México. 2. ed. México: Fondo de Cultura Económica, 1989. Tomo II. v. 2.

PAZ, Octavio. Sor Juana Inés de la Cruz o las trampas de la fe. 4. ed. México: Fondo de Cultura Económica, 1990.

POETAS do Século de Ouro Espanhol/Poetas del siglo de oro español. Seleção e tradução de Anderson Braga Horta; Fernando Mendes e José Jeronymo Rivera; estudo introdutório de Manuel Morillo Caballero. Brasília: Thesaurus; Consejería de Educacíon y Ciencia de la Embajada de España, 2000. (Coleção Orellana - Colección Orellana; 12)

PULPO. In: DICCIONARIO de Autoridades (O-R). Madrid: Real Academia Española, 1737. Disponível em: http://ntlle.rae.es/ntlle/ SrvltGUISalirNtlle. Acesso em: 15 abr. 2020.

REVÉS. In: DICCIONARIO de la lengua Española. Madrid: Real Academia Española, 2019. Disponível em: http://dle.rae. es/?id=WOGDOdG. Acesso em: 08 abr. 2020.

REVÉS. In: DICIONÁRIO da Língua Portuguesa. Lisboa: Priberam Informática, 2008-2020. Disponível em: https://www.priberam.pt/DLPO/ revés. Acesso em: 10 abr. 2020. 
SOLANA, Maite. Las fuentes documentales en la práctica de la traducción literaria. In: GARCÍA YEBRA, Valentín; GONZALO GARCÍA, Consuelo (ed.). Manual de documentación para la traducción Lliteraria. Madri: Arco Libros, 2005. p. 247-266.

TAJO. In: DICCIONARIO de la lengua Española. Madrid: Real Academia Española, 2019. Disponível em: http://dle.rae.es/?id=YxyAqjV. Acesso em: 8 abr. 2020.

TALHO. In: DICIONÁRIO da Língua Portuguesa. Lisboa: Priberam Informática, 2008-2020. Disponível em: https://www.priberam.pt/DLPO/ talho. Acesso em: 10 abr. 2020.

VEGA, Lope de. Arte nuevo de hacer comedias en este tiempo. Alicante: Biblioteca Virtual Miguel de Cervantes, 2003. Disponível em: http:// migre.me/u7PLZ. Acesso em: 8 abr. 2020.

VENUTI, Lawrence. Escândalos da tradução. Tradução de Laureano Pelegrin, Lucinéia Marcelino Villela, Marileide Dias Esqueda, Valéria Biondo. Bauru: Edusc, 2002.

Recebido em: 22 de abril de 2020. Aprovado em: 17 de setembro de 2020. 